Esta obra está sob o direito de Licença Creative Commons Atribuição 4.0 Internacional.

\title{
PELE DE TILÁPIA (Oreochromis niloticus) COMO CURATIVO BIOLÓGICO OCLUSIVO NO TRATAMENTO DE QUEIMADURAS: REVISÃO INTEGRATIVA DA LITERATURA
}

\author{
Raissa Marques Vanderlei Barbosa ${ }^{1}$ \\ Ariane Cavalcante Kecé Araújo ${ }^{2}$ \\ Andrea Marques Vanderlei Fregadolli ${ }^{3}$ \\ Fernanda Santos Azevedo ${ }^{4}$
}

\section{RESUMO}

A pele da Tilápia do Nilo (Oreochromis niloticus), em testes com animais, mostra ser um excelente biomaterial no tratamento de lesões. Nos testes, a pele da Tilápia provou ser bastante semelhante a pele humana, portanto, esse biomaterial pode ser utilizado como curativo biológico oclusivo no local das feridas, para que haja uma boa regeneração na região lesionada, sendo elas superficiais ou profundas. O objetivo deste foi integrar a produção científica do xenoenxerto de Tilápia do Nilo com o tratamento de feridas cutâneas, sejam superficiais ou profundas, em lesões leves à graves, realçando esse tipo de tratamento como mais uma opção viável para a regeneração e recuperação da pele. Trata-se de uma revisão sistemática integrativa qualitativa. Os descritores estruturados no DeCS, Burns, Injuries, Cichlids, Skin, Tilápia e o registro de entrada de injuries, (Wounds), foram utilizados nas varreduras das seguintes bases de busca: BVS, Science Direct; Pub Med; World Science, Periódicos da Capes e Google Acadêmico. O período da pesquisa bibliográfica compreendeu os meses de fevereiro a setembro de 2020. Os resultados encontrados sobre o tema foram um total de 1.020 .132 publicações nos bancos de dados, sendo 34.194 artigos disponíveis, após os filtros aplicados e obedeceram aos critérios de inclusão 20 artigos. Fica evidenciado que a pele da Tilápia se assemelha à pele humana morfologicamente e fisiologicamente, apresentando colágeno do tipo I, duas vezes mais que na pele humana, regenerando assim, a lesão com mais rapidez. Em comparação com o que já é utilizado no mercado, o curativo biológico da pele da Tilápia se destaca não somente pelo seu custo benefício e abundância no Brasil, mas pelo seu desempenho e eficácia como um inovador curativo biológico oclusivo. A criação do primeiro banco de pele animal do Brasil e a elaboração de seus protocolos e etapas para poder produzir uma pele segura para o tratamento de feridas, é fundamental para nortear futuros bancos semelhantes no mundo. O tratamento com a pele mostra-se eficaz no tratamento de lesões cutâneas, devido a sua boa aderência ao leito das feridas, contribuindo para uma regeneração da pele mais rápida e com menor sofrimento. Conclui-se que as pesquisas em torno deste inovador biomaterial comprovaram ser mais eficaz que outros produtos já utilizados no mercado, com a diminuição da dor instantaneamente e da

\footnotetext{
1 raissamarquesvb96@gmail.com

2 arianenunes708@gmail.com

3 andrea.ferreira@famed.ufal.br

${ }^{4}$ nanda_azevedoo@hotmail.com
} 
perda hídrica, com aumento da regeneração celular, otimizando o tempo de cicatrização e tratamento, além de ter um baixo custo e a matéria prima ser abundante.

Descritores: Tratamento. Oreochromis niloticus. Feridas e lesões. 


\section{INTRODUÇÃO}

A pele é o maior órgão do corpo humano e possui um teor de regeneração natural, todavia em casos de feridas cutâneas ou queimaduras, esse processo poderá demorar muito por meio natural, com possibilidade de infecção e até morte se não tratada corretamente, sem mencionar o quadro álgico causada por este tipo de lesão (SAYED et al., 2019).

Por ano no Brasil ocorre cerca de um milhão de acidentes relacionados às lesões de pele, sendo a maioria queimaduras de II e III grau, onde as queimaduras de II acontecem à dilatação das veias, uma parte do plasma transborda fazendo bolhas na pele, já nas de III graus é uma lesão mais grave onde pode provocar a destruição de parte da pele e da sua camada mais profunda assim atingindo a camada adiposa também, no qual $10 \%$ dos indivíduos que sofrem esses acidentes não procuram o ambiente hospitalar. Os pacientes que buscam serviços médicos recorrem à rede pública de saúde, no qual, no qual, o paciente fica hospitalizado e o tratamento é utilizado com fármacos. $\mathrm{Na}$ rede privada, os indivíduos podem contar com a ajuda de materiais biossintéticos para o auxílio na cicatrização das feridas cutâneas, contudo, o alto custo desses materiais, faz com que haja uma busca maior por materiais com um preço mais baixo, mas que a sua eficácia seja similar ou superior a esses materiais (LEONTSINIS et al., 2018; ALVES et al., 2015).

Para que ocorra uma boa regeneração cutânea, pode ser feita uma enxertia por meio da aplicação da pele de Tilápia do Nilo (Oreochromis niloticus), pois é mais acessível e eficaz no tratamento de lesões e com um baixo nível álgico por não haver trocas de curativos (SAYED et al., 2019).

O Brasil apesar de possuir grande dimensão territorial, contém apenas quatro bancos de pele ativos, localizados em: Hospital das clínicas em São Paulo (SP), Santa Casa de Misericórdia em Porto Alegre (RS), Instituto de Medicina Integral Professor Fernando Figueira - IMIP de Recife (PE) e no NPDM - Núcleo de Pesquisa e Desenvolvimento de Medicamentos, da Universidade Federal do Ceará, em Fortaleza. Mostrando ser bastante escasso o material para tratamentos cutâneos, já que só se consegue 1\%-100\% de peles para enxertias nesses tratamentos (ALVES et al., 2015; LEONTSINIS, et al. 2018; LIMA JÚNIOR et al., 2019).

No mundo, os fármacos são uma das primeiras escolhas para o tratamento de lesões cutâneas, porém os mesmos não possuem uma boa eficácia sob as queimaduras de II e III grau, uma alternativa também utilizada em casos de lesões deste tipo são cirurgias reparadoras. 
Porém, só há de ser bem sucedida por meio de uma boa regeneração das mesmas. Um tratamento promissor é o da utilização do curativo Quiosan (CS) em combinação com o biológico, o colágeno presente na pele de Tilápia do Nilo, além de transparecer ser um bom biomaterial no tratamento de lesões ele pode ajudar significativamente, podendo vim a ajudar de forma considerável nas cirurgias plásticas se necessário (OUYANG et al., 2018).

A pele da Tilápia do Nilo (Oreochromis niloticus), usada como curativo biológico oclusivo mostrou ser um biomaterial promissor para o tratamento das lesões cutâneas. Os testes realizados em animais foram bastante satisfatórios, acredita-se que também será eficiente no tratamento em humanos. Para que tenha esse tecido como curativo biológico é necessário fazer uso da piscicultura. Esses animais são criados em tanques e monitorados para que cheguem ao peso adequado para o abate. Logo, após é feito a retirada de sua pele, que deve ser feita a higienização e esterilização, para que o uso do xenoenxerto seja eficaz e seguro quando enxertados em humanos (LIMA JÚNIOR et al., 2017).

Em estudos realizados
recentemente, pode-se perceber o
aprimoramento do uso da pele de Tilápia do
Nilo (Oreochromis niloticus) em
tratamentos de queimaduras, mostrando-se

eficaz nessa modalidade no ramo de enxertia de materiais biológicos, já que o mesmo se adapta de forma branda e faz com que os indivíduos que necessitam fazer a utilização do mesmo não sintam incômodos, demostrando uma boa aderência ao leito das lesões, assim não precisam ser realizadas as trocas dos curativos como outros produtos já utilizados no mercado, manifestando-se uma queda absoluta no nível de dor desses pacientes (LIMA JÚNIOR et al., 2019).

Segundo MIRANDA, M. J. B (2018), o uso desse novo curativo biológico previne as perdas hidroeletrolíticas da pele, evita a contaminação por bactérias, proporciona a cicatrização do tecido epitelial e contribui na formação de novas células de granulação para a enxertia.

Com o avanço das pesquisas, tem-se buscado um biomaterial natural de ciclídeos que supra as seguintes necessidades: aderência ao leito das lesões, uma boa tração, compressão, e um custo acessível de materiais biossintéticos, que sejam acessíveis e de fácil reprodução. A pele da Tilápia do Nilo (Oreochromis niloticus), em testes com animais, provou ser um excelente biomaterial no tratamento de lesões. Nos testes realizados em humanos, esse material poderá ser utilizado como curativo oclusivo na região das feridas cutâneas, para que haja uma boa regeneração no local, sejam elas 
superficiais ou profundas (MIRANDA,

BRANDT 2019; ALVES et al., 2015).

O objetivo deste estudo foi realizar uma busca de evidências na literatura para identificar, agrupar e sintetizar o conhecimento produzido acerca dos benefícios do xenoenxerto de Tilápia do Nilo no tratamento de queimaduras.Foi desenvolvida uma pesquisa de revisão integrativa, que seguiu as seguintes etapas: Escolha da estratégia de busca: cruzamento de descritores por meio do operador booleano AND, OR; uso de aspas nos politermos escritor com mais de um termo (para que a varredura de artigos científicos contemplem o termo exato); uso de descritores estruturados (codificados) no DECS ou MESH; uso de filtros nas bibliotecas virtuais; uso de descritores em inglês e português (para ampliar o número de artigos); string de busca: Burns OR (wounds and injuries) AND cichlids AND skin; queimaduras AND feridas AND tilápia; o período da pesquisa bibliográfica compreendeu os meses de fevereiro a setembro de 2020; critérios de inclusão e exclusão.

Quadro 1. Etapas da Revisão Integrativa.

\begin{tabular}{|c|c|c|c|c|}
\hline ETAPA & $\begin{array}{l}\text { TÓPICOS DE } \\
\text { CADA ETAPA }\end{array}$ & \multicolumn{3}{|c|}{ DETALHAMENTO DE CADA TÓPICO } \\
\hline \multirow[t]{3}{*}{$1^{\mathrm{a}}$} & Tema & \multicolumn{3}{|c|}{$\begin{array}{l}\text { Pele de Tilápia (Oreochromis niloticus) como curativo biológico } \\
\text { oclusivo no tratamento de feridas cutâneas: revisão integrativa da } \\
\text { literatura }\end{array}$} \\
\hline & Objetivo geral & \multicolumn{3}{|c|}{$\begin{array}{l}\text { Realizar uma busca de evidências na literatura para identificar, } \\
\text { agrupar e sintetizar o conhecimento produzido acerca dos } \\
\text { benefícios do xenoenxerto de Tilápia do Nilo no tratamento de } \\
\text { queimaduras. }\end{array}$} \\
\hline & $\begin{array}{l}\text { Estratégias de } \\
\text { busca }\end{array}$ & \multicolumn{3}{|c|}{$\begin{array}{l}\text { Cruzamento de descritores e uso de uma string de busca por } \\
\text { meio dos operadores booleanos AND, OR; } \\
\text { Uso de aspas nos politermos (descritor com mais de um termo) }\end{array}$} \\
\hline & & \multicolumn{3}{|c|}{$\begin{array}{l}\text { para que a varredura de artigos científicos contemplasse o } \\
\text { termo exato; } \\
\text { Uso de descritores estruturados (codificação) no DECS ou } \\
\text { MESH para aumentar o poder de escalabilidade nas varreduras; } \\
\text { Uso de metadados (filtros) nas bibliotecas virtuais; } \\
\text { Uso de descritores em inglês e português para ampliar o } \\
\text { número de artigos. }\end{array}$} \\
\hline & \multirow{3}{*}{$\begin{array}{l}\text { Bancos de } \\
\text { terminologias }\end{array}$} & Banco & \multicolumn{2}{|c|}{ Link } \\
\hline & & DeCS & http://decs.bvs.br & \\
\hline & & $\mathrm{MeSH}$ & \multicolumn{2}{|c|}{ https://www.ncbi.nlm.nih.gov/mesh } \\
\hline & \multirow[t]{2}{*}{$\begin{array}{l}\text { Descritores } \\
\text { livres e } \\
\text { estruturados }\end{array}$} & Descritor & DeCS (Registro) & $\begin{array}{l}\text { MeSH } \\
\text { (Identificador } \\
\text { Único) }\end{array}$ \\
\hline & & Burns, Queimaduras & 2088 & D002056 \\
\hline
\end{tabular}




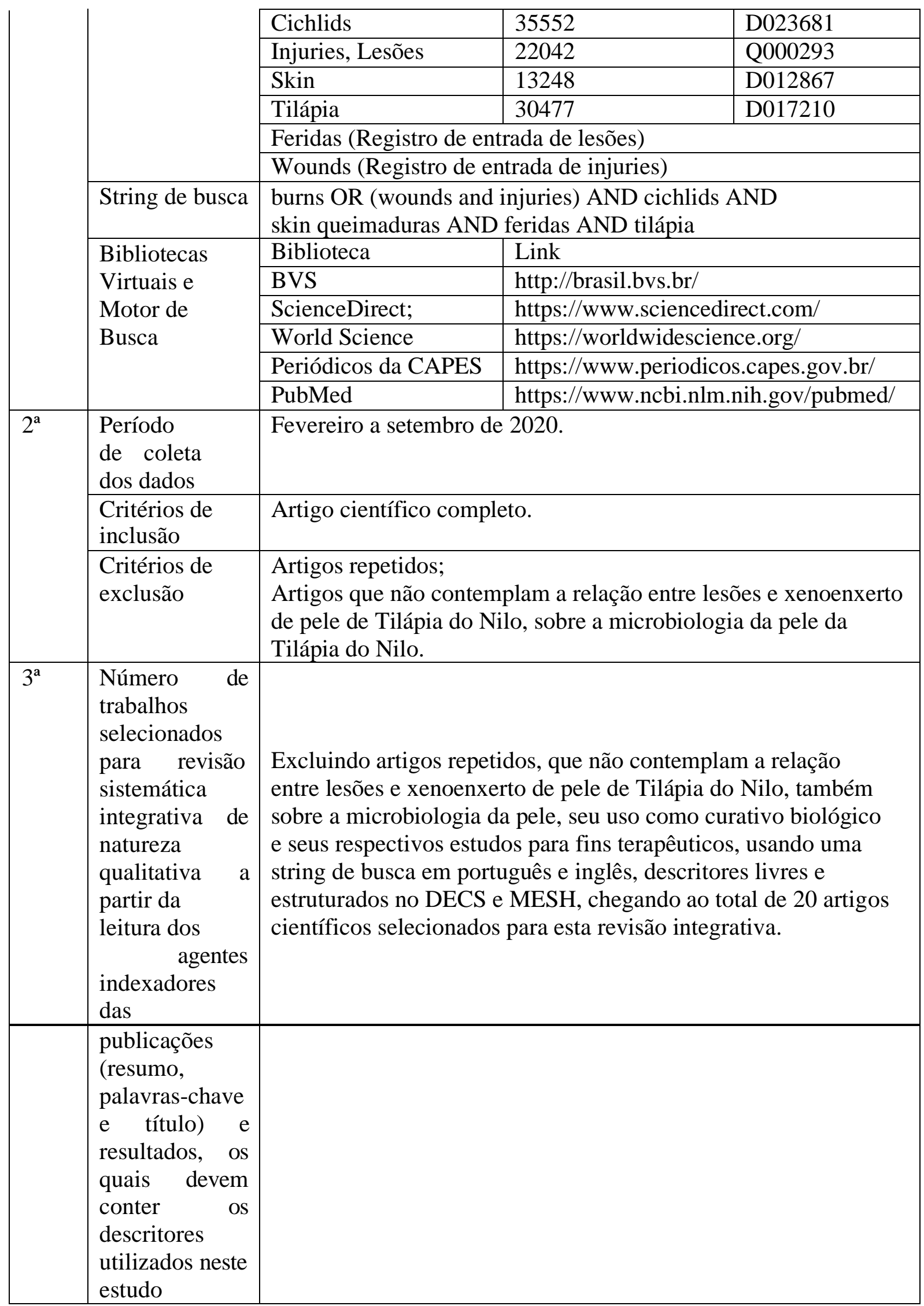




\begin{tabular}{|c|c|c|c|c|}
\hline $4^{\mathrm{a}}$ & $\begin{array}{l}\text { Categorias a } \\
\text { serem obtidas } \\
\text { com a análise } \\
\text { dos trabalhos } \\
\text { científicos } \\
\text { investigados }\end{array}$ & \multicolumn{3}{|c|}{$\begin{array}{l}\text { Foram desenvolvidas na pesquisa por meio da obtenção } \\
\text { da frequência de palavras usando o site Word Art. } \\
\text { Ver em discussão. }\end{array}$} \\
\hline $5^{a}$ & $\begin{array}{l}\text { Análise, } \\
\text { interpretação e }\end{array}$ & \multicolumn{3}{|c|}{$\begin{array}{l}\text { Está disponível em "Resultados e Discussão" do artigo de } \\
\text { revisão integrativa que será desenvolvido neste projeto. }\end{array}$} \\
\hline \multirow[t]{5}{*}{$6^{\mathrm{a}}$} & \multirow{4}{*}{$\begin{array}{l}\text { Tecnologias } \\
\text { digitais a } \\
\text { serem } \\
\text { utilizadas }\end{array}$} & $\begin{array}{l}\text { Tecnologia } \\
\text { (software } \\
\text { ou website) }\end{array}$ & Link & Utilidade \\
\hline & & $\begin{array}{l}\text { Google } \\
\text { Translation }\end{array}$ & https://translate.google.com.br/ & $\begin{array}{l}\text { Tradução de } \\
\text { idiomas }\end{array}$ \\
\hline & & Mendeley & $\begin{array}{l}\text { https://www.mendeley.com/do } \\
\text { wnload-desktop/ }\end{array}$ & $\begin{array}{l}\text { Gerenciar } \\
\text { citações e } \\
\text { referências }\end{array}$ \\
\hline & & WordArt & https://wordart.com/ & $\begin{array}{l}\text { Obter } \\
\text { frequências de } \\
\text { palavras }\end{array}$ \\
\hline & $\begin{array}{l}\text { Apresentação } \\
\text { da revisão em } \\
\text { formato de } \\
\text { artigo, o qual } \\
\text { contemplará } \\
\text { propostas para } \\
\text { estudos futuros }\end{array}$ & \multicolumn{3}{|c|}{ Artigo desenvolvido. } \\
\hline
\end{tabular}

Fonte: Autoria própria.

\section{RESULTADOS}

Foram detectadas na Tabela 1 , 973.258 publicações científicas nos bancos de dados, das quais 121.944 eram artigos científicos disponíveis após o uso dos filtros. Entretanto, obedeceram aos critérios de inclusão 20 artigos científicos (Tabela 1), sendo submetidos as etapas de revisão sistemática integrativa qualitativa (Quadro 2). Entre eles: 9 foram estudos primários (originais), 7 eram de revisão (estudos secundários), 1 de nota prévia, 2 relatos (de caso e de experiência), sendo um último de revisão crítica. Quanto ao ano de publicação: 2 estudos foram publicados no ano de 2020; 6 no ano de 2019; 7 no ano de 2018; 2 em 2017, 1 em 2016, e 1 último em 2015, o que evidência a atualidade do tema. Ainda, 8 artigos estavam escritos em português e 12 em inglês.

A tabela 1, abaixo, corresponde ao quantitativo das varreduras realizadas. 
Tabela 1. Publicações disponíveis na BVS, Science Direct, World Science, PubMed, Periódicos da CAPES e Google Acadêmico usando cruzamento de descritores.

\begin{tabular}{|c|c|c|c|c|}
\hline $\begin{array}{l}\text { STRING DE } \\
\text { BUSCA }\end{array}$ & $\begin{array}{l}\text { BIBLIOTECAS } \\
\text { VIRTUAIS }\end{array}$ & $\begin{array}{c}\text { TOTAL DE } \\
\text { PUBLICAÇÕE } \\
\text { S SEM O } \\
\text { FILTRO } \\
\text { “ASSUNTO } \\
\text { PRINCIPAL” }\end{array}$ & $\begin{array}{c}\text { TEXTOS } \\
\text { COMPLETO } \\
\text { S } \\
\text { DISPONÍVEIS } \\
\text { APÓS } \\
\text { APLICAR OS } \\
\text { FILTROS }\end{array}$ & $\begin{array}{c}\text { TEXTOS } \\
\text { APROVEITADO } \\
\text { S NA REVISÁO } \\
\text { SISTEMÁTICA } \\
\text { INTEGRATIV } \\
\text { A } \\
\text { QUALITATIV } \\
\text { A }\end{array}$ \\
\hline & $\begin{array}{l}\text { World } \\
\text { Science }\end{array}$ & 1.023 & 482 & 2 \\
\hline \multirow{4}{*}{$\begin{array}{c}\text { BURNS OR } \\
\text { (WOUNDS } \\
\text { AND } \\
\text { INJURIES) } \\
\text { AND } \\
\text { CICHLIDS } \\
\text { AND SKIN }\end{array}$} & Science Direct & 483.978 & 99.393 & 1 \\
\hline & $\begin{array}{l}\text { Periódico } \\
\text { s } \\
\text { CAPES }\end{array}$ & 488.113 & 21.978 & 3 \\
\hline & Pub Med & 10 & 6 & 2 \\
\hline & BVS Brasil & 5 & 5 & 4 \\
\hline $\begin{array}{c}\text { QUEIMADURA } \\
\text { S } \\
\text { AND FERIDAS } \\
\text { AND TILÁPIA }\end{array}$ & $\begin{array}{l}\text { Google } \\
\text { Acadêmic } \\
\text { o }\end{array}$ & 129 & 80 & 8 \\
\hline \multicolumn{2}{|c|}{$\begin{array}{c}\text { TOTA } \\
\text { L }\end{array}$} & 973.258 & 121.944 & 20 \\
\hline
\end{tabular}

Fonte: Autoria própria.

Foram encontrados 20 artigos científicos em revistas brasileiras e internacionais, 8 estão escritos em português e 12 em inglês. Utilizado a string de busca (Burns OR (wounds and injuries) AND cichlids AND skin em 12 artigos científicos e Queimaduras AND feridas AND tilápia em 8 .

Quadro 2. Levantamento de publicações científicas de acordo com os critérios de inclusão, referidos no Quadro 1 de material e método.

\begin{tabular}{|c|c|c|c|c|c|c|}
\hline $\mathrm{N}^{\circ}$ & Autoria/Ano & Periódico & Idioma & Objetivo & Conclusão & $\begin{array}{l}\text { String de } \\
\text { busca }\end{array}$ \\
\hline 1 & $\begin{array}{l}\text { ALVES et al., } \\
(2015)\end{array}$ & Português & $\begin{array}{l}\text { Revista } \\
\text { Brasileira } \\
\text { de } \\
\text { Queimadur } \\
\text { as }\end{array}$ & $\begin{array}{l}\text { Caracterizar a pele } \\
\text { de Tilápia do Nilo, } \\
\text { como uma possível } \\
\text { fonte de } \\
\text { biomaterial para } \\
\text { enxertia, a partir de } \\
\text { suas características } \\
\text { físicas (resistência } \\
\text { à tração), } \\
\text { histomorfológicas } \\
\text { e da tipificação da } \\
\text { composição do } \\
\text { colágeno. }\end{array}$ & $\begin{array}{l}\text { A pele de } \\
\text { Tilápia possui } \\
\text { características } \\
\text { microscópicas } \\
\text { semelhantes à } \\
\text { estrutura } \\
\text { morfológica da } \\
\text { pele humana e } \\
\text { elevada } \\
\text { resistência e } \\
\text { extensão à } \\
\text { tração em } \\
\text { quebra e a }\end{array}$ & $\begin{array}{l}\text { Burns } \\
\text { OR } \\
\text { (wounds } \\
\text { and } \\
\text { injuries) } \\
\text { AND } \\
\text { cichlids } \\
\text { AND } \\
\text { skin }\end{array}$ \\
\hline
\end{tabular}




\begin{tabular}{|c|c|c|c|c|c|c|}
\hline & & & & & $\begin{array}{l}\text { derme desta } \\
\text { pele é } \\
\text { composta por } \\
\text { feixes } \\
\text { organizados de } \\
\text { fibras de } \\
\text { colágeno } \\
\text { denso, do tipo } \\
\text { I, o que traz } \\
\text { importância } \\
\text { para seu uso } \\
\text { clínico. }\end{array}$ & \\
\hline 2 & $\begin{array}{l}\text { OUYANG } \\
\text { et al., } \\
\text { (2018) }\end{array}$ & Inglês & $\begin{array}{l}\text { Internation } \\
\text { al Journal } \\
\text { of } \\
\text { Biological } \\
\text { Macromole } \\
\text { cules }\end{array}$ & $\begin{array}{l}\text { Desenvolver um } \\
\text { curativo promissor } \\
\text { para queimaduras. }\end{array}$ & $\begin{array}{l}\text { O experimento } \\
\text { antimicrobiano } \\
\text { revelou que os } \\
\text { CSMP } \\
\text { exibiram } \\
\text { atividades } \\
\text { antibacterianas } \\
\text { significativas. } \\
\text { Comparado, o } \\
\text { CSMP tinha } \\
\text { mais } \\
\text { habilidades } \\
\text { para promover } \\
\text { a proliferação } \\
\text { e migração } \\
\text { celular, assim, } \\
\text { tendo uma boa } \\
\text { eficiência na } \\
\text { cicatrização de } \\
\text { feridas. O } \\
\text { tempo de } \\
\text { cicatrização da } \\
\text { ferida foi } \\
\text { menor no } \\
\text { grupo tratado } \\
\text { com CSMP do } \\
\text { que aqueles no } \\
\text { grupo controle } \\
\text { e grupos de } \\
\text { pomadas para } \\
\text { queimaduras } \\
\text { disponíveis no } \\
\text { mercado. }\end{array}$ & $\begin{array}{l}\text { Burns } \\
\text { OR } \\
\text { (wounds } \\
\text { and } \\
\text { injuries) } \\
\text { AND } \\
\text { cichlids } \\
\text { AND } \\
\text { skin }\end{array}$ \\
\hline 3 & $\begin{array}{l}\text { ALVES et al., } \\
\text { (2018) }\end{array}$ & Inglês & $\begin{array}{l}\text { Cell Tissue } \\
\text { Bank }\end{array}$ & $\begin{array}{l}\text { Analisar a pele da } \\
\text { Tilápia do Nilo, } \\
\text { microscopicamente } \\
\text {, bem como suas } \\
\text { propriedades } \\
\text { tensiométricas, } \\
\text { enquanto } \\
\text { determina a sua } \\
\text { proporção de } \\
\text { colágeno tipo I / III }\end{array}$ & $\begin{array}{l}\text { A esterilização } \\
\text { química e a } \\
\text { radiosterilizaçã } \\
\text { o nas doses de } \\
25 \mathrm{kGy} \text { e } 30 \\
\text { kGy são } \\
\text { eficazes na } \\
\text { preparação da } \\
\text { pele da Tilápia } \\
\text { do Nilo para }\end{array}$ & $\begin{array}{l}\text { Burns } \\
\text { OR } \\
\text { (wounds } \\
\text { and } \\
\text { injuries) } \\
\text { AND } \\
\text { cichlids } \\
\text { AND } \\
\text { skin }\end{array}$ \\
\hline
\end{tabular}




\begin{tabular}{|c|c|c|c|c|c|c|}
\hline & & & & $\begin{array}{l}\text { após ser preparado } \\
\text { por diferentes } \\
\text { métodos de } \\
\text { esterilização. }\end{array}$ & $\begin{array}{l}\text { uso como } \\
\text { curativo } \\
\text { biológico, e } \\
\text { esses métodos } \\
\text { não alteram } \\
\text { sua } \\
\text { microscópica } \\
\text { nem suas } \\
\text { propriedades } \\
\text { tensiométricas. }\end{array}$ & \\
\hline 4 & $\begin{array}{l}\text { MIRAND A, } \\
\text { BRANDT, } \\
\text { (2019) }\end{array}$ & Português & $\begin{array}{l}\text { Revista } \\
\text { Brasileira } \\
\text { de Cirurgia } \\
\text { Plástica }\end{array}$ & $\begin{array}{l}\text { Avaliar a eficácia } \\
\text { da utilização da } \\
\text { pele da Tilápia do } \\
\text { Nilo como } \\
\text { curativo biológico } \\
\text { oclusivo no } \\
\text { manejo e } \\
\text { tratamento de } \\
\text { queimaduras de } \\
\text { segundo grau } \\
\text { superficial e } \\
\text { profundo em } \\
\text { adultos em } \\
\text { comparação ao } \\
\text { curativo à base de } \\
\text { hidrofibra com } \\
\text { prata (Aquacel } \\
\text { AG®) }\end{array}$ & $\begin{array}{l}\text { O tratamento } \\
\text { com a pele da } \\
\text { Tilápia em } \\
\text { queimaduras é } \\
\text { eficaz. Os } \\
\text { pacientes } \\
\text { tratados com o } \\
\text { curativo com a } \\
\text { pele da Tilápia } \\
\text { do Nilo, a } \\
\text { média de dias } \\
\text { de tratamento } \\
\text { foi similar aos } \\
\text { tratados com } \\
\text { curativo } \\
\text { Aquacel AG® } \\
\text { para a } \\
\text { completa } \\
\text { cicatrização ou } \\
\text { reepitelização } \\
\text { da ferida. } \\
\text { Não houve } \\
\text { inferioridade } \\
\text { da referência } \\
\text { de dor e de } \\
\text { trocas de } \\
\text { curativos dos } \\
\text { pacientes após } \\
\text { a aplicação dos } \\
\text { dois curativos. }\end{array}$ & $\begin{array}{l}\text { Burns } \\
\text { OR } \\
\text { (wounds } \\
\text { and } \\
\text { injuries) } \\
\text { AND } \\
\text { cichlids } \\
\text { AND }\end{array}$ \\
\hline 5 & $\begin{array}{l}\text { LIMA } \\
\text { JÚNIOR et } \\
\text { al., (2019) }\end{array}$ & Português & $\begin{array}{l}\text { The } \\
\text { Journals of } \\
\text { Gerontolog } \\
\text { y. } \\
\text { Series A, } \\
\text { Biological } \\
\text { Sciences } \\
\text { and } \\
\text { Medical } \\
\text { Sciences }\end{array}$ & $\begin{array}{l}\text { Avaliar a eficácia } \\
\text { da pele de Tilápia } \\
\text { do Nilo como um } \\
\text { xenoenxerto para o } \\
\text { tratamento de } \\
\text { queimaduras de } \\
\text { espessura parcial } \\
\text { em crianças. }\end{array}$ & $\begin{array}{l}\text { Neste estudo, a } \\
\text { pele da Tilápia } \\
\text { mostrou boa } \\
\text { aderência ao } \\
\text { leito da ferida, } \\
\text { reduzindo o } \\
\text { número de } \\
\text { trocas de } \\
\text { curativos e a } \\
\text { quantidade de } \\
\text { anestésicos } \\
\text { usados, } \\
\text { auxiliando no } \\
\text { processo de } \\
\text { cicatrização, }\end{array}$ & $\begin{array}{l}\text { Burns } \\
\text { OR } \\
\text { (wounds } \\
\text { and } \\
\text { injuries) } \\
\text { AND } \\
\text { cichlids } \\
\text { AND } \\
\text { skin }\end{array}$ \\
\hline
\end{tabular}




\begin{tabular}{|c|c|c|c|c|c|c|}
\hline & & & & & $\begin{array}{l}\text { diminuindo a } \\
\text { perda de } \\
\text { líquidos, } \\
\text { proporcionand } \\
\text { o benefícios } \\
\text { aos pacientes e } \\
\text { profissionais } \\
\text { de saúde, } \\
\text { reduzindo a } \\
\text { carga de } \\
\text { trabalho geral. } \\
\text { O resultado } \\
\text { dos } \\
\text { tratamentos foi } \\
\text { semelhante ao } \\
\text { tratamento } \\
\text { convencional } \\
\text { com } \\
\text { Sulfadiazina } \\
\text { de prata. }\end{array}$ & \\
\hline 6 & $\begin{array}{l}\text { ZHOU et al., } \\
(2017)\end{array}$ & Inglês & $\begin{array}{l}\text { Internacion } \\
\text { al Journal } \\
\text { Nanomedic } \\
\text { ine }\end{array}$ & $\begin{array}{l}\text { Neste estudo, o } \\
\text { colágeno de peixe } \\
\text { foi obtido da pele } \\
\text { da Tilápia. A } \\
\text { resistência à tração } \\
\text { e a atividade } \\
\text { antibacteriana das } \\
\text { nanofibras Col / } \\
\text { BG em S. aureus } \\
\text { (uma das } \\
\text { principais bactérias } \\
\text { durante a infecção } \\
\text { da } \\
\text { pele) foram } \\
\text { estudadas. }\end{array}$ & $\begin{array}{l}\text { Os resultados } \\
\text { in vivo } \\
\text { mostraram que } \\
\text { as nanofibras } \\
\text { de Col/BG } \\
\text { poderiam } \\
\text { efetivamente } \\
\text { induzir a } \\
\text { regeneração da } \\
\text { pele na área da } \\
\text { ferida. Este } \\
\text { estudo sugere } \\
\text { que as } \\
\text { nanofibras Col } \\
\text { / BG de peixes } \\
\text { multifuncionai } \\
\text { s têm um } \\
\text { grande } \\
\text { potencial para } \\
\text { uso como } \\
\text { curativo. }\end{array}$ & $\begin{array}{l}\text { Burns } \\
\text { OR } \\
\text { (wounds } \\
\text { and } \\
\text { injuries) } \\
\text { AND } \\
\text { cichlids } \\
\text { AND } \\
\text { skin }\end{array}$ \\
\hline 7 & $\begin{array}{l}\text { LIMA } \\
\text { JÚNIOR et } \\
\text { al., (2019) }\end{array}$ & Inglês & $\begin{array}{l}\text { Revista } \\
\text { Brasileira } \\
\text { de Cirurgia } \\
\text { Plástica }\end{array}$ & $\begin{array}{l}\text { Apresentar a } \\
\text { elaboração, } \\
\text { desenvolvimento e } \\
\text { implementação do } \\
\text { primeiro banco de } \\
\text { pele animal do } \\
\text { Brasil } \\
\text { para tratar } \\
\text { queimaduras. }\end{array}$ & $\begin{array}{l}\text { Este trabalho } \\
\text { permitiu a } \\
\text { criação do } \\
\text { primeiro Brasil } \\
\text { banco de pele } \\
\text { de animal com } \\
\text { estrutura, } \\
\text { elaboração e } \\
\text { padronização } \\
\text { de todos os } \\
\text { procedimentos } \\
\text { para a } \\
\text { produção de } \\
\text { pele de }\end{array}$ & $\begin{array}{l}\text { Burns } \\
\text { OR } \\
\text { (wounds } \\
\text { and } \\
\text { injuries) } \\
\text { AND } \\
\text { cichlids } \\
\text { AND } \\
\text { skin }\end{array}$ \\
\hline
\end{tabular}




\begin{tabular}{|c|c|c|c|c|c|c|}
\hline & & & & & Tilápia. & \\
\hline 8 & $\begin{array}{l}\text { GONZÁL EZ, } \\
\text { MAYER., } \\
\text { (2019) }\end{array}$ & Inglês & $\begin{array}{l}\text { Veterinary } \\
\text { Clinics of } \\
\text { North } \\
\text { America: } \\
\text { Exotic } \\
\text { Animal } \\
\text { Practice }\end{array}$ & $\begin{array}{l}\text { Revisar técnicas de } \\
\text { terapia de pressão } \\
\text { de feridas, } \\
\text { fotobiomodulação } \\
\text { [laser terapia], } \\
\text { estimulação } \\
\text { elétrica terapia } \\
\text { [EST], } \\
\text { ultrassonografia } \\
\text { terapêutica [TU], } \\
\text { oxigenoterapia } \\
\text { hiperbárica } \\
\text { [OHB]) e outros } \\
\text { avanços no } \\
\text { tratamento de } \\
\text { feridas (expansores } \\
\text { de pele, } \\
\text { xenoenxertos e } \\
\text { substitutos } \\
\text { autólogos da pele) } \\
\text { em espécies de } \\
\text { animais exóticos. }\end{array}$ & $\begin{array}{l}\text { Independentem } \\
\text { ente do tipo de } \\
\text { ferida, da } \\
\text { corrente ou da } \\
\text { polaridade } \\
\text { aplicada, EST } \\
\text { (especialmente } \\
\text { corrente } \\
\text { direta de baixa } \\
\text { intensidade e } \\
\text { corrente } \\
\text { pulsada de } \\
\text { Baixa } \\
\text { intensidade), } \\
\text { facilita a } \\
\text { cicatrização de } \\
\text { feridas e } \\
\text { melhora a } \\
\text { sobrevivência } \\
\text { dos retalhos e } \\
\text { músculos } \\
\text { cutâneos. O } \\
\text { uso da EST } \\
\text { aumenta a } \\
\text { deposição de } \\
\text { colágeno, mas } \\
\text { tem pouco ou } \\
\text { nenhum efeito } \\
\text { na formação de } \\
\text { reticulação e } \\
\text { realinhamento } \\
\text { do colágeno de } \\
\text { maneira } \\
\text { congruente, } \\
\text { portanto, } \\
\text { justificando } \\
\text { novos } \\
\text { estudos. }\end{array}$ & $\begin{array}{l}\text { Burns } \\
\text { OR } \\
\text { (wounds } \\
\text { and } \\
\text { injuries) } \\
\text { AND } \\
\text { cichlids } \\
\text { AND } \\
\text { skin }\end{array}$ \\
\hline 9 & $\begin{array}{l}\text { SAYED et al., } \\
(2019)\end{array}$ & Inglês & $\begin{array}{l}\text { Advances } \\
\text { wounds } \\
\text { care }\end{array}$ & $\begin{array}{l}\text { Revisar os } \\
\text { paradigmas } \\
\text { clássicos dos } \\
\text { substitutos } \\
\text { biológicos da pele } \\
\text { usados como } \\
\text { primeira cobertura } \\
\text { e avaliamos as } \\
\text { recentes } \\
\text { descobertas e } \\
\text { abordagens } \\
\text { clínicas adaptadas } \\
\text { à cobertura de } \\
\text { lesões por } \\
\text { queimaduras, com } \\
\text { ênfase em }\end{array}$ & $\begin{array}{l}\text { Substitutos } \\
\text { dérmicos tem } \\
\text { um importante } \\
\text { papel na } \\
\text { regeneração da } \\
\text { pele, pois } \\
\text { permitem } \\
\text { rápida } \\
\text { cobertura da } \\
\text { ferida, } \\
\text { reduzindo a } \\
\text { lesão e o risco } \\
\text { de infecção } \\
\text { fornecendo } \\
\text { uma barreira } \\
\text { física aos }\end{array}$ & $\begin{array}{l}\text { Burns } \\
\text { OR } \\
\text { (wounds } \\
\text { and } \\
\text { injuries) } \\
\text { AND } \\
\text { cichlids } \\
\text { AND } \\
\text { skin }\end{array}$ \\
\hline
\end{tabular}




\begin{tabular}{|c|c|c|c|c|c|c|}
\hline & & & & $\begin{array}{l}\text { abordagens } \\
\text { inovadoras } \\
\text { baseadas em } \\
\text { células. }\end{array}$ & $\begin{array}{l}\text { patógenos, } \\
\text { reduzindo } \\
\text { indiretamente } \\
\text { o tempo de } \\
\text { internação e } \\
\text { custos globais. } \\
\text { Avanços foram } \\
\text { feitos } \\
\text { ultimamente e } \\
\text { melhorias nos } \\
\text { resultados } \\
\text { clínicos podem } \\
\text { ser esperados } \\
\text { principalmente } \\
\text { com a } \\
\text { abordagem de } \\
\text { terapias } \\
\text { celular. São } \\
\text { necessárias } \\
\text { isenções } \\
\text { hospitalares } \\
\text { para garantir } \\
\text { segurança aos } \\
\text { pacientes } \\
\text { sem impedir os } \\
\text { avanços nas } \\
\text { terapias. }\end{array}$ & \\
\hline 10 & $\begin{array}{l}\text { LI et al., } \\
\text { (2018) }\end{array}$ & Inglês & $\begin{array}{l}\text { Cell and } \\
\text { Tissue } \\
\text { Research }\end{array}$ & $\begin{array}{l}\text { Revisar os } \\
\text { princípios básicos } \\
\text { do tratamento de } \\
\text { feridas e } \\
\text { resumimos os } \\
\text { desenvolvimentos } \\
\text { recentes } \\
\text { envolvendo } \\
\text { métodos } \\
\text { terapêuticos } \\
\text { tradicionais e de } \\
\text { alta tecnologia que } \\
\text { levam à cura } \\
\text { rápida e a } \\
\text { melhores } \\
\text { resultados } \\
\text { cosméticos. } \\
\text { Estudos futuros } \\
\text { devem explorar } \\
\text { uma abordagem } \\
\text { mais econômica, } \\
\text { conveniente e } \\
\text { eficiente } \\
\text { para a cicatrização } \\
\text { cutânea de feridas. }\end{array}$ & $\begin{array}{l}\text { No tratamento } \\
\text { de pacientes } \\
\text { com feridas, os } \\
\text { princípios } \\
\text { básicos de } \\
\text { cuidados } \\
\text { precisam ser } \\
\text { geralmente } \\
\text { seguidos e } \\
\text { métodos } \\
\text { adicionais } \\
\text { ajudarão a } \\
\text { avançar no } \\
\text { tratamento } \\
\text { terapêutico. É } \\
\text { importante } \\
\text { explorar os } \\
\text { tratamentos } \\
\text { acessíveis, } \\
\text { convenientes e } \\
\text { abordagens } \\
\text { eficientes para } \\
\text { a cicatrização } \\
\text { cutânea de } \\
\text { feridas. }\end{array}$ & $\begin{array}{l}\text { Burns } \\
\text { OR } \\
\text { (wounds } \\
\text { and } \\
\text { injuries) } \\
\text { AND } \\
\text { cichlids } \\
\text { AND } \\
\text { skin }\end{array}$ \\
\hline 11 & $\begin{array}{l}\text { LIMA } \\
\text { JÚNIOR et } \\
\text { al., (2016) }\end{array}$ & Inglês & $\begin{array}{l}\text { Journal of } \\
\text { Health \& }\end{array}$ & $\begin{array}{l}\text { Analisar a } \\
\text { microbiota da } \\
\text { cavidade oral e do }\end{array}$ & $\begin{array}{l}\text { Diante de } \\
\text { alguns } \\
\text { resultados }\end{array}$ & $\begin{array}{l}\text { Burns } \\
\text { OR }\end{array}$ \\
\hline
\end{tabular}




\begin{tabular}{|c|c|c|c|c|c|c|}
\hline & & & $\begin{array}{l}\text { Biological } \\
\text { Sciences }\end{array}$ & $\begin{array}{l}\text { tecido da pele na } \\
\text { Tilápia do Nilo } \\
\text { (Oreochromis } \\
\text { niloticus), } \\
\text { comercialmente } \\
\text { criado no Brasil. }\end{array}$ & $\begin{array}{l}\text { encontrados no } \\
\text { estudo e } \\
\text { considerando a } \\
\text { ausência de } \\
\text { sinais } \\
\text { infecciosos nas } \\
\text { amostras de } \\
\text { peixes, } \\
\text { conclui-se que } \\
\text { os valores } \\
\text { CFU's } \\
\text { encontrados } \\
\text { neste estudo } \\
\text { consistem em } \\
\text { colonização / } \\
\text { microbiota }\end{array}$ & $\begin{array}{l}\text { (wounds } \\
\text { and } \\
\text { injuries) } \\
\text { AND } \\
\text { cichlids } \\
\text { AND } \\
\text { skin }\end{array}$ \\
\hline 12 & $\begin{array}{l}\text { GIMENEZ } \\
\text { et al., } \\
\text { (2019) }\end{array}$ & Português & $\begin{array}{l}\text { Enfermage } \\
\text { m Atual In } \\
\text { Derme }\end{array}$ & $\begin{array}{l}\text { O objetivo é } \\
\text { demonstrar que já } \\
\text { é possível o } \\
\text { tratamento de } \\
\text { queimaduras de } \\
\text { uma forma que } \\
\text { venha diminuir o } \\
\text { sofrimento do } \\
\text { paciente. }\end{array}$ & $\begin{array}{l}\text { O estudo } \\
\text { revelou que } \\
\text { além do alívio } \\
\text { da dor do } \\
\text { paciente e } \\
\text { maior eficácia } \\
\text { do curativo, o } \\
\text { custo do } \\
\text { tratamento fica } \\
\text { mais barato, } \\
\text { comparado ao } \\
\text { tratamento } \\
\text { convencional. } \\
\text { Não } \\
\text { precisando } \\
\text { refazer o } \\
\text { curativo. Esse } \\
\text { tratamento tem } \\
\text { reduzido as } \\
\text { dores em } 30 \text { a } \\
\text { 50\%, o que é } \\
\text { de muita } \\
\text { significância } \\
\text { para a } \\
\text { qualidade do } \\
\text { tratamento. }\end{array}$ & $\begin{array}{l}\text { Queimad } \\
\text { uras } \\
\text { AND } \\
\text { feridas } \\
\text { AND } \\
\text { tilápia }\end{array}$ \\
\hline 13 & $\begin{array}{l}\text { NUNES, } \\
\text { LOPES., } \\
\text { (2018) }\end{array}$ & Português & $\begin{array}{l}\text { Revista } \\
\text { Eletrônica } \\
\text { da } \\
\text { Faculdade } \\
\text { de Ceres }\end{array}$ & $\begin{array}{l}\text { Descrever os } \\
\text { curativos } \\
\text { utilizados em } \\
\text { pacientes que } \\
\text { sofreram } \\
\text { queimaduras de } \\
\text { terceiro grau. Com } \\
\text { o objetivo de } \\
\text { contribuir para } \\
\text { uma assistência e } \\
\text { ações adequadas, } \\
\text { partindo da } \\
\text { necessidade de }\end{array}$ & $\begin{array}{l}\text { O enfermeiro } \\
\text { que atua em } \\
\text { uma unidade } \\
\text { de queimados } \\
\text { deve comandar } \\
\text { estudos cujos } \\
\text { resultados } \\
\text { possam gerar } \\
\text { resultados que } \\
\text { direcionem o } \\
\text { cuidado das } \\
\text { feridas } \\
\text { provocadas por }\end{array}$ & $\begin{array}{l}\text { Queimad } \\
\text { uras } \\
\text { AND } \\
\text { feridas } \\
\text { AND } \\
\text { tilápia }\end{array}$ \\
\hline
\end{tabular}




\begin{tabular}{|c|c|c|c|c|c|c|}
\hline & & & & $\begin{array}{l}\text { enfatizar o papel } \\
\text { do profissional de } \\
\text { enfermagem frente } \\
\text { ao tratamento das } \\
\text { lesões causadas } \\
\text { por exposição a } \\
\text { agentes térmicos, } \\
\text { elétricos ou } \\
\text { radioativos. }\end{array}$ & $\begin{array}{l}\text { queimaduras. } \\
\text { Vê-se ao longo } \\
\text { desse estudo a } \\
\text { importância da } \\
\text { assepsia } \\
\text { durante a } \\
\text { realização dos } \\
\text { curativos para } \\
\text { que estes não } \\
\text { adquiram } \\
\text { infecções. É de } \\
\text { suma } \\
\text { relevância que } \\
\text { a equipe de } \\
\text { enfermagem } \\
\text { esteja atenta as } \\
\text { possíveis } \\
\text { alterações das } \\
\text { feridas por } \\
\text { queimaduras } \\
\text { durante a } \\
\text { realização do } \\
\text { curativo, para } \\
\text { que se possa } \\
\text { planejar } \\
\text { cuidados de } \\
\text { maneira eficaz. }\end{array}$ & \\
\hline 14 & $\begin{array}{l}\text { LEONTSI } \\
\text { NIS et al., } \\
\text { (2018) }\end{array}$ & Inglês & $\begin{array}{l}\text { Revista } \\
\text { Brasileira } \\
\text { de } \\
\text { Queimadur } \\
\text { as }\end{array}$ & $\begin{array}{l}\text { Criar um protocolo } \\
\text { que norteará os } \\
\text { processos e } \\
\text { garantirá a } \\
\text { qualidade de todas } \\
\text { as etapas do } \\
\text { processamento da } \\
\text { pele da Tilápia, } \\
\text { tornando possível a } \\
\text { adoção de } \\
\text { procedimentos } \\
\text { únicos, e padrões } \\
\text { baseados neste } \\
\text { documento, que } \\
\text { garantirá a } \\
\text { qualidade e } \\
\text { a segurança da } \\
\text { pele de Tilápia } \\
\text { para aplicação } \\
\text { clínica e } \\
\text { possibilitará a } \\
\text { implementação } \\
\text { destes } \\
\text { procedimentos em } \\
\text { outros bancos } \\
\text { semelhantes pelo } \\
\text { país e pelo mundo }\end{array}$ & $\begin{array}{l}\text { O papel do } \\
\text { enfermeiro é } \\
\text { fundamental } \\
\text { para a } \\
\text { elaboração e } \\
\text { implantação de } \\
\text { um protocolo } \\
\text { gerenciando } \\
\text { adequadament } \\
\text { e, assegurando } \\
\text { o } \\
\text { estabeleciment } \\
\text { o de regras, } \\
\text { uniformização } \\
\text { dos } \\
\text { procedimentos } \\
\text { e rotinas de } \\
\text { processo. Este } \\
\text { trabalho } \\
\text { permitirá a } \\
\text { criação de } \\
\text { manuais e } \\
\text { controles que } \\
\text { irão nortear os } \\
\text { processos e } \\
\text { garantir a } \\
\text { qualidade de } \\
\text { todas as etapas }\end{array}$ & $\begin{array}{l}\text { Queimad } \\
\text { uras } \\
\text { AND } \\
\text { feridas } \\
\text { AND } \\
\text { tilápia }\end{array}$ \\
\hline
\end{tabular}




\begin{tabular}{|c|c|c|c|c|c|c|}
\hline & & & & & $\begin{array}{l}\text { do } \\
\text { processamento } \\
\text { da pele da } \\
\text { Tilápia do } \\
\text { primeiro } \\
\text { Banco de Pele } \\
\text { Animal do } \\
\text { Brasil. }\end{array}$ & \\
\hline 15 & $\begin{array}{l}\text { TORRISI } \\
\text { et al., } \\
\text { (2018) }\end{array}$ & Português & $\begin{array}{l}\text { Anais da } \\
\text { Faculdade } \\
\text { de } \\
\text { Medicina } \\
\text { de Olinda }\end{array}$ & $\begin{array}{l}\text { O uso da pele da } \\
\text { Tilápia do Nilo } \\
\text { (Oreochromis } \\
\text { niloticus), para } \\
\text { tratamento médico } \\
\text { das queimaduras } \\
\text { de segundo grau } \\
\text { superficial e } \\
\text { profunda, é uma } \\
\text { nova opção } \\
\text { terapêutica. }\end{array}$ & $\begin{array}{l}\text { Esse é um dos } \\
\text { poucos relatos } \\
\text { de caso } \\
\text { publicados na } \\
\text { literatura } \\
\text { mundial sobre } \\
\text { a utilização da } \\
\text { pele dá Tilápia } \\
\text { como curativo } \\
\text { biológico de } \\
\text { origem de } \\
\text { animal de } \\
\text { habitat } \\
\text { aquático para } \\
\text { tratamento das } \\
\text { queimaduras. } \\
\text { Essa } \\
\text { alternativa } \\
\text { poderá além de } \\
\text { reduzir a dor e } \\
\text { o tempo da } \\
\text { cura das } \\
\text { feridas, reduzir } \\
\text { custos no } \\
\text { tratamento e } \\
\text { evitar } \\
\text { complicações, } \\
\text { relacionadas as } \\
\text { infeccões. }\end{array}$ & $\begin{array}{l}\text { Queimad } \\
\text { uras } \\
\text { AND } \\
\text { feridas } \\
\text { AND } \\
\text { tilápia }\end{array}$ \\
\hline 16 & $\begin{array}{l}\text { SILVA et al., } \\
\text { (2019) }\end{array}$ & Inglês & $\begin{array}{l}\text { Brazilian } \\
\text { Journal } \\
\text { Veterinary } \\
\text { res. and } \\
\text { Animal } \\
\text { Science }\end{array}$ & $\begin{array}{l}\text { Avaliar se a pele } \\
\text { de Tilápia utilizada } \\
\text { como curativo } \\
\text { oclusivo melhora o } \\
\text { processo de } \\
\text { cicatrização em } \\
\text { dois equinos } \\
\text { machos adultos da } \\
\text { raça Mangalarga } \\
\text { Machador, os } \\
\text { quais apresentam } \\
\text { feridas crônicas. }\end{array}$ & $\begin{array}{l}\text { Em equinos, a } \\
\text { utilização de } \\
\text { curativo de } \\
\text { pele de Tilápia } \\
\text { parece } \\
\text { diminuir o } \\
\text { tempo de } \\
\text { cicatrização e } \\
\text { permite a } \\
\text { redução do } \\
\text { número de } \\
\text { trocas de } \\
\text { curativos a } \\
\text { cada dois dias } \\
\text { para uma vez } \\
\text { por semana. } \\
\text { Isso implica } \\
\text { em menos }\end{array}$ & $\begin{array}{l}\text { Queimad } \\
\text { uras } \\
\text { AND } \\
\text { feridas } \\
\text { AND } \\
\text { tilápia }\end{array}$ \\
\hline
\end{tabular}




\begin{tabular}{|c|c|c|c|c|c|c|}
\hline & & & & & $\begin{array}{l}\text { estresse e dor } \\
\text { para o animal } \\
\text { devido a } \\
\text { menor } \\
\text { manipulação e } \\
\text { menor custo de } \\
\text { tratamento. } \\
\text { Além disso, } \\
\text { permite evitar } \\
\text { a utilização } \\
\text { de antibióticos. }\end{array}$ & \\
\hline 17 & $\begin{array}{l}\text { LIMA } \\
\text { JÚNIOR et } \\
\text { al., (2017) }\end{array}$ & Português & $\begin{array}{l}\text { Brazilian } \\
\text { Journal } \\
\text { Veterinary } \\
\text { res. and } \\
\text { Animal } \\
\text { Science }\end{array}$ & $\begin{array}{l}\text { Avaliar a } \\
\text { utilização da pele } \\
\text { de Tilápia do Nilo } \\
\text { como curativo } \\
\text { oclusivo } \\
\text { temporário nas } \\
\text { queimaduras de } \\
\text { segundo grau } \\
\text { superficial e } \\
\text { profunda em ratos. }\end{array}$ & $\begin{array}{l}\text { A pele da } \\
\text { Tilápia } \\
\text { apresentou boa } \\
\text { aderência no } \\
\text { leito das } \\
\text { feridas } \\
\text { induzidas por } \\
\text { queimaduras } \\
\text { nos ratos } \\
\text { testados, } \\
\text { interferindo } \\
\text { positivamente } \\
\text { no processo } \\
\text { cicatricial e } \\
\text { não causando } \\
\text { alterações } \\
\text { relevantes nos } \\
\text { parâmetros } \\
\text { hematológicos } \\
\text { e bioquímicos } \\
\text { de função renal } \\
\text { e hepática, } \\
\text { sendo um } \\
\text { potencial } \\
\text { curativo } \\
\text { biológico para } \\
\text { o tratamento } \\
\text { desta natureza. }\end{array}$ & $\begin{array}{l}\text { Queimad } \\
\text { uras } \\
\text { AND } \\
\text { feridas } \\
\text { AND } \\
\text { tilápia }\end{array}$ \\
\hline 18 & $\begin{array}{l}\text { MIRAND } \\
(2018)\end{array}$ & Português & $\begin{array}{l}\text { Anais da } \\
\text { Faculdade } \\
\text { de } \\
\text { Medicina } \\
\text { de Olinda }\end{array}$ & $\begin{array}{l}\text { Descrever o estado } \\
\text { da arte do uso da } \\
\text { pele da Tilápia do } \\
\text { Nilo como } \\
\text { curativo biológico } \\
\text { no tratamento de } \\
\text { queimaduras. }\end{array}$ & $\begin{array}{l}\text { Atualmente, } \\
\text { várias } \\
\text { pesquisas estão } \\
\text { em andamento } \\
\text { para garantir } \\
\text { amplamente o } \\
\text { uso da pele de } \\
\text { Tilápia do Nilo } \\
\text { como produto } \\
\text { inovador, } \\
\text { seguro, } \\
\text { nacional e de } \\
\text { baixo custo } \\
\text { como proposta } \\
\text { de curativos }\end{array}$ & $\begin{array}{l}\text { Queimad } \\
\text { uras } \\
\text { AND } \\
\text { feridas } \\
\text { AND } \\
\text { tilápia }\end{array}$ \\
\hline
\end{tabular}




\begin{tabular}{|c|c|c|c|c|c|c|}
\hline & & & & & $\begin{array}{l}\text { ideal } \\
\text { direcionado ao } \\
\text { paciente } \\
\text { queimado. }\end{array}$ & \\
\hline 19 & MEI, (2020) & Inglês & $\begin{array}{l}\text { Journal of } \\
\text { Agricultura } \\
1 \text { and Food } \\
\text { Chemistry }\end{array}$ & $\begin{array}{l}\text { Investigar a } \\
\text { relação entre os } \\
\text { peptídeos de } \\
\text { colágeno, } \\
\text { cicatrização de } \\
\text { feridas e } \\
\text { colonização da } \\
\text { microflora da } \\
\text { ferida pela } \\
\text { administração de } \\
\text { murina modelo } \\
\text { com peptídeos de } \\
\text { colágeno da pele } \\
\text { de Salmo salar e } \\
\text { peptídeos de } \\
\text { colágeno da pele } \\
\text { de } \\
\text { Tilápia nilótica. }\end{array}$ & $\begin{array}{l}\text { A cura } \\
\text { acelerada no } \\
\text { grupo de } \\
\text { peptídeo de } \\
\text { colágeno } \\
\text { mostra que a } \\
\text { microflora da } \\
\text { ferida, como } \\
\text { Leuconostoc, } \\
\text { Enterococus, e } \\
\text { bacilos têm um } \\
\text { efeito positivo } \\
\text { na cicatrização } \\
\text { de ferida. }\end{array}$ & $\begin{array}{l}\text { Burns } \\
\text { OR } \\
\text { (wounds } \\
\text { and } \\
\text { injuries) } \\
\text { AND } \\
\text { cichlids } \\
\text { AND } \\
\text { skin }\end{array}$ \\
\hline 20 & $\begin{array}{l}\text { NASCIME } \\
\text { NTO et al., } \\
\text { (2020) }\end{array}$ & Português & $\begin{array}{l}\text { Temas em } \\
\text { Saúde }\end{array}$ & $\begin{array}{l}\text { Identificar a } \\
\text { eficácia do uso da } \\
\text { pele de Tilápia no } \\
\text { tratamento de } \\
\text { queimaduras. }\end{array}$ & $\begin{array}{l}\text { Sua estrutura } \\
\text { morfológica é } \\
\text { semelhante à } \\
\text { pele humana e } \\
\text { possuidora de } \\
\text { componentes } \\
\text { que auxiliam } \\
\text { na cicatrização } \\
\text { das lesões. } \\
\text { Portanto, a } \\
\text { pele da Tilápia } \\
\text { deve ser } \\
\text { utilizada no } \\
\text { tratamento de } \\
\text { queimaduras, } \\
\text { diminuindo o } \\
\text { sofrimento do } \\
\text { paciente, uma } \\
\text { vez que não } \\
\text { necessita de } \\
\text { trocas, } \\
\text { auxiliando na } \\
\text { recuperação, } \\
\text { por possuir } \\
\text { propriedades } \\
\text { que estimulam } \\
\text { a regeneração } \\
\text { celular e } \\
\text { impedem a } \\
\text { contaminação } \\
\text { externa, uma } \\
\text { vez aderindo } \\
\text { ao leito da }\end{array}$ & $\begin{array}{l}\text { Queimad } \\
\text { uras } \\
\text { AND } \\
\text { feridas } \\
\text { AND } \\
\text { tilápia }\end{array}$ \\
\hline
\end{tabular}




\begin{tabular}{|l|l|l|l|}
\hline & & & $\begin{array}{l}\text { lesão, e, } \\
\text { consequenteme } \\
\text { nte, ajudando a } \\
\text { minimizar } \\
\text { custos com } \\
\text { tratamento de } \\
\text { queimados no } \\
\text { sistema de } \\
\text { saúde. }\end{array}$ \\
\hline
\end{tabular}

Fonte: autoria própria.

O site WordArt foi utilizado para obter os termos mais frequentes nos objetivos e conclusões dos 20 artigos selecionados. Os termos mais prevalentes foram pele $(n=51)$, Tilápia $(n=34)$, tratamento $(\mathrm{n}=32)$, queimadura $(\mathrm{n}=28)$, ferida $(n=27)$, curativo $(n=26)$, cicatrização $(n=16)$, colágeno $(n=13)$ e paciente $(n=12)$.

Tabela 2. Frequência das palavras obtidas dos artigos científicos analisados.

\begin{tabular}{|c|c|c|}
\hline Palavras & Quantidade & Artigos (Quadro 2) \\
\hline Pele & 51 & $1 ; 3 ; 4 ; 5 ; 6 ; 7 ; 8 ; 9 ; 11 ; 12 ; 14 ; 15 ; 16 ; 17 ; 18 ; 19 ; 20$. \\
\hline Tilápia & 34 & $1 ; 2 ; 3 ; 4 ; 5 ; 6 ; 7 ; 11 ; 12 ; 14 ; 15 ; 16 ; 17 ; 18 ; 19 ; 20$. \\
\hline Tratamento & 32 & $4 ; 5 ; 8 ; 10 ; 12 ; 13 ; 15 ; 16 ; 17 ; 18 ; 20$. \\
\hline Queimadura & 28 & $2 ; 4 ; 5 ; 7 ; 9 ; 12 ; 13 ; 15 ; 17 ; 18 ; 20$. \\
\hline Ferida & 27 & $2 ; 4 ; 5 ; 6 ; 8 ; 9 ; 10 ; 13 ; 15 ; 16 ; 17 ; 19$. \\
\hline Curativo & 26 & $2 ; 3 ; 4 ; 5 ; 6 ; 12 ; 13 ; 15 ; 16 ; 17 ; 18$. \\
\hline Cicatrização & 16 & $2 ; 4 ; 5 ; 6 ; 8 ; 10 ; 13 ; 16 ; 19 ; 20$. \\
\hline Colágeno & 13 & $12 ; 2 ; 3 ; 6 ; 8 ; 19$. \\
\hline Paciente & 12 & $4 ; 5 ; 9 ; 10 ; 12 ; 13 ; 18 ; 20$. \\
\hline
\end{tabular}

Fonte: autoria própria.

A partir dessa frequência de microscópicas, fisiológicas e morfológicas palavras que se obteve as categorias da pele da Tilápia do Nilo em comparação temáticas a saber: Características com a pele humana, curativos biológicos e 
sua evolução e comparação com outros curativos já utilizados no mercado, elaboração e protocolo do primeiro banco de pele animal do Brasil e tratamento de

\section{DISCUSSÃO}

Características

microscópicas, fisiológicas e morfológicas da pele da Tilápia do Nilo em comparação com a pele humana.

A pele humana foi analisada sob microscopia ótica, onde foi possível evidenciar um revestimento de epitélio pavimentoso estratificado hiper orto paraqueratinizado, com trechos de atrofia, sob o qual via-se tecido conjuntivo fibroso, com aumentada atividade colagênica, células inflamatórias mononucleares dispersas e vasos sanguíneos, por vezes, dilatados. Na derme superficial e na profunda, havia tecido conjuntivo fibroso denso não modelado, com as fibras colágenas dispostas em diferentes direções (ALVES et al., 2018).

A derme superficial da Tilápia é composta por tecido conjuntivo frouxo, permeado por vasos sanguíneos de calibres variados, com fibras de colágenos paralelos e finos, além de melanóforos subepiteliais e melanofagos dispersos. Na derme profunda, foi observado espessas fibras colágenas organizadas, compactadas, em disposição paralela/horizontal e transversal/vertical, perpendiculares à superfície da pele. $\mathrm{O}$ queimaduras e cicatrização por outras lesões cutâneas usando a pele de Tilápia do Nilo, de acordo com as palavras mais frequentes.

colágeno tipo I mostrou-se significantemente aumentada na pele da Tilápia em relação a pele humana. O colágeno configura-se como um dos principais componentes dos biomateriais, devido à sua característica de orientar e de definir a maioria dos tecidos, além de possibilitar biodegradabilidade e biocompatibilidade, que favorecem a sua aplicação, sendo assim a possível utilização da pele da Tilápia como curativo biológico por ser semelhante a estrutura morfológica da pele (ALVES et al., 2018).

As etapas aplicadas em trono deste biomaterial foram as seguintes: coleta de amostra, protocolo de esterilização química para pele de Tilápia do Nilo, teste microbiológico, esterilização adicional por radiação, análise histológica, análise histoquímica, análise de propriedades tensiométricas e análise estatística. Após a aplicação das etapas de análise histológica, análise histoquímica foi possível observar feixes de colágenos do tipo I distribuídos horizontalmente e longitudinalmente na derme, com a aplicação da etapa de esterilização adicional por radiação pode-se observar que não havia nenhuma diferenciação aparente no tipo de colágeno 
encontrado neste tecido. Ao ser finalizadas as etapas este biomaterial se mostrou um tanto quanto promissor para ser utilizado na medicina regenerativa já que em seus testes iniciais já se mostrava eficaz no uso em lesões cutâneas (ALVES et al., 2018).

Foram coletadas 20 amostras da cavidade oral e da pele da Tilápia do Nilo, cada um pesando mais ou menos um quilo, juntamente essas amostras foram analisadas quantitativamente em ágar de sangue de ovelha e ágar chromiD. Onze espécies diferentes de bactérias foram identificadas em placas das respectivas análises. As espécies gram- negativas foram predominantes. A carga microbiana foi inferior a $100.000 \mathrm{UFC} / \mathrm{g}$ de tecido em todas as amostras estudadas, considerando a ausência de sinais infecciosos nas amostras de peixe, concluindo assim uma colonização da microbiota normal e não infecciosa (LIMA JÚNIOR et al., 2016).

Revelou-se que os grupos de peptídeos encontrados na pele da Tilápia, promovem de forma positiva na cicatrização das lesões cutâneas da pele, com o uso desta pele como biomaterial pode-se observar que a utilização dela no local das lesões apresentou uma melhorar significativa em poucos dias de uso e a nova pele que começava a se regenerar apresentava-se mais lisa e a dor diminuiu de forma branda (MEI et al., 2020).

Percebe-se que as características tanto morfológicas, fisiológicas quanto histológicas deste animal promovem similaridade à pele humana pelas suas altas concentrações de colágeno tipo I, que também está presente na pele humana em menor concentração, por essas taxas de colágenos presentes na pele da Tilápia do Nilo faz com que a pele se regenere mais rápido, mostrando a eficácia desse biomaterial biológico no tratamento das lesões.

\section{Curativos biológicos e sua evolução e comparação com outros curativos já utilizados no mercado.}

Um curativo biológico é utilizado geralmente em feridas mais complexas no caso das mais graves, como queimaduras de II e III graus, e feridas profundas, que precisam de um esforço maior para se regenerarem. São os casos de enxertos de peles, seja de origem animal (xenógenos), ou de origem humana (autógenos), do próprio paciente ou de outros doadores (alógenos). Os curativos mais utilizados no tratamento de feridas superficiais são: Sulfadiazina de prata a $1 \%$, hidrofibra de prata, autoenxerto epitelial em cultura (CEA) e cultura autoenxerto dermo epidérmico (CDEA).Estão sendo feitos de materiais como espumas de silicone semipermeáveis, hidrocolóides, hidrogéis e hidrofibra. A busca por um biomaterial temporário de baixo custo, com uma 
elevada eficácia de aderência a leitos de lesões cutâneas da pele, e que apresenta ser promissor na medicina regenerativa tem sido difícil (OUYANG et al., 2018; TORRISI et al., 2018; SILVA et al., 2019; SAYED et al., 2019).

Um biomaterial que se mostrou promissor foi a pele da Tilápia já que a mesma possui feixes de colágenos do tipo I, esse tipo de colágeno de tilápia possui esponjas nanofibras de eletrofiação que foram desenvolvidas para curativos de lesões, já que apresentavam boa estabilidade térmica e uma significativa propriedade de expansão, promove significativa proliferação de queratinócitos e ajuda na diferenciação da epiderme por uma expressão gênica positiva. A pele de tilápia tem baixas taxas de rejeição ao ser aplicada na pele, possui uma boa aderência ao leito das lesões, a utilização do mesmo como curativo oclusivo revelou ser uma boa proposta já que não precisa ser realizada a troca constantemente (OUYANG et al., 2018; TORRISI et al., 2018; SILVA et al., 2019; SAYED et al., 2019).

As lesões cutâneas são consideradas um problema para a saúde pública, uma vez que a reabilitação de pessoas que sofreram lesões dermatológicas se torna prolongada e o tratamento é considerado de alto custo. Outros tipos de curativos oclusivos também podem ser utilizados no tratamento destas lesões como: prata, hidrogéis, substitutos de pele, espuma de silicone, curativo úmido e petrolato. Esses tratamentos também favorecem na regeneração assim como diminuem o risco de contaminação. Outro ponto importante, é a redução do quadro álgico no promissor curativo biológico de pele da Tilápia do Nilo (MIRANDA, M. J. B, 2018).

Coberturas do tipo sulfadiazina de prata, materiais substitutivos de pele, oxigenoterapia hiperbárica foram as mais utilizadas no mercado da indústria farmacêutica no tratamento de feridas, em suas diferentes fases, por isso a utilização de qualquer produto para estes fins, deve seguir um rigoroso protocolo, para identificar a real eficácia de cada produto para cada lesão. Sendo assim, o enfermeiro responsável atuante na unidade de queimados precisa comandar estudos que obtenham resultados que melhorem o cuidado das feridas e lesões, estando preparado psicologicamente, emocionalmente e cientificamente para cuidar de pacientes lesionados, já que no organismo desses pacientes há alterações fisiológicas muito bruscas por causa das queimaduras (NUNES, LOPES, 2018).

Os testes cujo curativo biológico foi submetido para testar a sua eficácia em torno de agentes antibacterianos se mostrou um tanto quanto significativo, para isso esse material passou por uma grande peneira de testes onde também pode ser observado que 
ele contribui de forma considerável no crescimento celular nos locais das lesões. $\mathrm{O}$ mesmo mostrou altas taxas de cicatrização em testes podendo se aproxima de quase $100 \%$ de cicatrização em testes in vitro (OUYANG et al., 2018).

Os substitutos de pele temporários têm uma alta eficiência na regeneração da pele por permitir uma rápida cobertura, diminuindo significativamente o risco de infecção, fornecendo uma barreira física contra patógenos. Ainda hoje são utilizados como métodos o uso de materiais biossintéticos temporários, porém estes possuem alto custo e uma saída para isso seria a utilização de biomateriais de baixo custo. Mas que seja eficaz e que possua uma boa apresentação na medicina regenerativa (SAYED et al., 2019).

O colágeno da Tilápia do Nilo é um ótimo biomaterial com seu baixo custo e abundância, em seus testes realizados em animais mostrou-se bastante eficaz no tratamento das lesões, já que tem uma boa aderência e tração significativa no leito das lesões; e contribui para a diminuição de contaminação de agentes infecciosos. E o curativo com base na pele de tilapia do Nilo não necessita ser trocado com tanta frequência tem se um tempo de uso um tanto quanto prolongado, para que dessa forma a pele lesionada consiga absorve o colágeno nela presente (SILVA et al., 2019).
Consequentemente, a utilização da pele de animais aquáticos, com base nas pesquisas tecnológicas de eletrofiação e incorporação de nanofibras de uma cama combinada pode produzir um curativo muito bom com propriedades especiais, já que essas nanofibras em aplicação por biomédicos como curativos se manifesta um tanto porosa. Esse material passou por testes de resistência, tração e a atividade antibacteriana com o uso dos produtos de $\mathrm{Col} / \mathrm{BG}$ em S. aureus (uma das principais bactérias durante a infecção de pele). Foram utilizadas algumas células no processo de cicatrização de lesões tais como HaCaTs, derme humana fibroblastos HDFs e células endoteliais foram as escolhidas. Foi feito um estudo, onde a capacidade dos HDFs cujo ajudam a secretar colágenos do tipo I e fatores de crescimento do endotélio vascular também foi investigada (ZHOU et al., 2017).

Após serem realizadas observações acerca do uso deste biomaterial a base de pele de Tilápia, viu-se benefícios, dos quais não se fez mais necessária a troca desse curativo de

forma diária, já que a pele da Tilápia permaneceu aderida aos leitos das lesões, só se fez necessária essa troca de curativo caso ele se desidrate, ou se desprenda da ferida, após uns 7-10 dias. As lesões obtiveram uma melhora considerável no processo de cicatrização com o uso deste biomaterial, 
pois as suas características morfológicas se assemelham a pele humana, pois possui o mesmo tipo de colágeno, sendo a do peixe duas vezes mais que a de humanos. (LIMA JUNIOR et al., 2017).

A pele da Tilápia apresenta uma morfologia próxima à da pele humana com os seus feixes densos de colágenos organizados, isso é o que auxilia na sua traçãolld e resistência na aderência aos leitos das lesões. Esses feixes de colágenos cujo á pele do peixe é constituído é do tipo I, que em sua pele é encontrado em maior abundância do que na pele humana, por este motivo esse biomaterial interage de forma tão significativa no tratamento de lesões (TORRISI et al., 2018).

O uso deste biomaterial como curativo biológico é totalmente eficiente e promissor no tratamento das lesões cutâneas e queimaduras, o mesmo pode se dizer que além de possuir baixo custo, tem uma boa aderência e tração nos leitos das lesões. Esse material pode ser encontrado em abundância e como as características desse biomaterial com as altas taxas de colágeno contribuem de forma gradativa na medicina regenerativa.

\section{Elaboração e protocolo do primeiro banco de pele animal do Brasil.}

As principais etapas para o beneficiamento da pele da Tilápia foram:
Organização e montagem do laboratório antes do recebimento da pele animal; armazenamento e transporte; limpeza e descontaminação; esterilização química e envelopamento das peles da Tilápia. De acordo com os padrões internacionais, a criação dos bancos deve ter: Regulação regional de acordo com as leis de saúde vigentes; organização administrativa; padrões para as instalações físicas dos bancos de tecidos; recuperação de tecidos com qualidade e padrões farmacêuticos e rastreabilidade dos processos de preservação. Foram realizados muitos estudos, como reconhecer a área física para montar o banco de peles de animais, visitas a bancos de peles, estabelecer processo de esterilização, dentre outros (LIMA JÚNIOR et al., 2019; LEONTSINIS et al., 2018).

De acordo com Lima Júnior, et al. (2019), o Banco de Pele de Animais Aquáticos do NPDM foi inaugurado em 2017 e tem como processo de melhoramento da pele da Tilápia as seguintes etapas: Organização e montagem do laboratório de cura e do Banco de pele de animais antes da chegada das peles; processamento e transporte; limpeza e descontaminação (com clorexidina a $2 \%$ ); esterilização química em $75 \%$ de glicerol; esterilização em glicerol a 100\% em banhomaria e embrulho duplo, dupla vedação, rotulagem e inventário. As peles 
processadas e identificadas são conservadas em uma geladeira. Essas peles são identificadas e catalogadas e enviadas ao Instituto de Pesquisa em Energia Nuclear de São Paulo, onde são irradiadas para 30 kGy e devolvidas ao laboratório de origem no NPDM, onde estão armazenados em uma geladeira para liberar tecido para uso a $2-4$ ${ }^{\circ} \mathrm{C}$, com validade de até 2 anos.

Para atender uma alta demanda de queimados, surge a ideia de usar a pele da Tilápia do Nilo como um subproduto para este tratamento. Para a construção do protocolo do banco de pele animal, foram efetuadas as seguintes etapas: visita técnica ao Banco de pele animal de Recife, onde foi planejado o levantamento das necessidades de insumos, controle de esterilização e organização do ambiente; identificação e descrição de todas as etapas do processamento da pele de Tilápia; elaboração de planilhas de relação de materiais necessários para o processamento da pele; e controle do gasto de material utilizado. O resultado permitirá a criação de vários manuais e controles, que irão conduzir os processos e garantir a qualidade de todas as etapas do processamento da pele da Tilápia do primeiro Banco de Pele Animal do Brasil (LEONTSINIS et al., 2018).

Assim, a elaboração e protocolos do primeiro banco de pele de animal do Brasil é imprescindível para o bom funcionamento do mesmo, para gerar uma pele de Tilápia do Nilo segura e saudável para os pacientes em tratamento de lesões cutâneas e para guiar futuros bancos de pele no Brasil e mundo afora, servindo como modelo.

\section{Tratamento de queimaduras e cicatrização por outras lesões cutâneas usando a pele de Tilápia do Nilo.}

As lesões de I e II grau são um grande desafio para equipe de enfermagem pelo potencial de infecções sendo a limpeza correta da ferida bastante importante para o tratamento das lesões para ser eficaz. A pele da Tilápia do Nilo provou-se eficaz como curativo biológico oclusivo em lesões de II grau em adultos, sendo a média de dias de tratamento menor, a dor e a substituição dos curativos foram semelhantes ao curativo Aquacel usado em estudos clínicos. Já é possível diminuir o sofrimento de pacientes queimados, não precisando trocar $\mathrm{o}$ curativo. Exaltando a eficácia desse tratamento no processo fisiológico, já que a pele da Tilápia tem duas vezes mais colágeno tipo I que a pele humana. O Brasil é um dos maiores produtores de peixes do mundo, representando a Tilápia 58,4\% dessa produção, a matéria prima é abundante, consequentemente barata (NUNES, LOPES, 2018; MIRANDA, BRANDT, 2019; GIMENEZ et al., 2019).

Segundo Zeng et al. (2018), a cicatrização de feridas cutâneas tem sido 
muito falada ultimamente e tem estimulado os pesquisadores a procurarem novos métodos de tratamento dessas lesões, com mais eficiência e de baixo custo. Várias abordagens foram criadas e aprimoradas nessas décadas. Para diminuir o custo da cicatrização de feridas, os cientistas e pesquisadores necessitam buscar alternativo ás abordagens atuais, de menor preço e maior eficiência, que é o caso da pele de Tilápia do Nilo, que é comumente descartada, mas recentemente vista como contém em sua pele peptídeos de colágeno que aceleram a cicatrização de feridas no tratamento de queimaduras. Seguindo sempre o princípio básico de cuidado, mas com novos métodos práticos e de qualidade para ajudar no manejo terapêutico, é muito importante abordar tratamentos mais acessíveis, convenientes e eficientes para a cicatrização de feridas cutâneas.

Provou-se que a pele da Tilápia do Nilo é eficaz como curativo biológico oclusivo em pacientes queimados, no tratamento eles tiveram menos dias ao todo, devido a boa aderência ao leito da pele, sendo similar ao curativo Aquacel, revitalizando e cicatrizando essa pele lesionada, a troca de peles e curativos foi menor usando a Tilápia, $60 \%$ dos pacientes não precisaram trocar as mesmas, comparado a Aquacel que foi de 53,3\%, quanto a dor não houve diferença significativa, porém após a aplicação da pele da Tilápia houve $87,7 \%$ de diminuição de dor na escala, sendo inferior a 5 pontos. $\mathrm{O}$ que mostra seu benefício nas lesões comparando ao curativo Aquacel (MIRANDA, BRANDT, 2019).

Em acordo, Gimenez et al. (2019) dizem que os ferimentos causados por queimaduras são bastante dolorosos, principalmente na troca dos curativos. $\mathrm{O}$ principal benefício de usar a pele da Tilápia como curativo biológico no tratamento de lesões cutâneas é a diminuição da dor e a redução de troca de curativos, devido sua boa aderência ao leito da ferida, evitando assim o sofrimento do paciente. Em 2017 houve uma pesquisa com 60 pessoas, e os resultados obtidos foram positivos, como o custo desse curativo é muito menor em relação aos já usados no mercado. Viu-se a diminuição das dores de $30 \%$ a $50 \%$. O Brasil produz 280 toneladas de Tilápia, sendo assim um dos maiores produtores do mundo, o que acaba barateando seu produto, tendo em vista sua utilização em alta demanda na medicina regenerativa no Brasil, com grande capacidade para exportação.

Entende-se que a qualidade da pele da Tilápia do Nilo e sua aplicação no tratamento de queimaduras é bastante eficaz, por estas peles serem semelhantes entre si morfologicamente, por possuírem elementos que auxiliam na cicatrização, por possuírem baixo custo, uma vez que o 
sistema de saúde utiliza de um alto investimento para o tratamento de lesões, sendo a pele de Tilápia do Nilo um bioproduto de alta qualidade. Com tudo a pele deve ser usada em xenoenxertos para tratamento de lesões pelos seus benefícios superiores a outros métodos já encontrados, como a diminuição da dor, do próprio sofrimento, da contaminação de bactérias por meio externo, boa aderência ao leito das lesões e diminuindo os custos do tratamento no sistema de saúde. Como é um bioproduto inovador, existem poucas pesquisas sobre, necessitando de mais pesquisas recentes com novas informações quanto seu uso (NASCIMENTO et al., 2020).

Observou-se que a pele da Tilápia tem uma microbiota não infecciosa, e estrutura morfológica semelhante a pele humana, tendo ainda mais composição de colágeno tipo I, revitalizando a pele, também foram feitos testes em ratos. Crianças $(n=30)$ avaliadas em Fortaleza, Brasil, com idades entre 2 a 12 anos, comprometidas com lesões superficiais. Nos testes com as crianças a remoção da pele não necessitou de analgesia, sendo removida apenas com um banho em água corrente, resultando no processo de hidratação, que enfraqueceu a pele, levando a quebra e derrapagem da mesma. O mesmo apresenta uma boa aderência ao leito da lesão, redução da troca de curativos, a quantidade de anestésicos usados no paciente, diminuindo a perda de líquidos, oferecendo benefícios ao paciente e também para os profissionais envolvidos, diminuindo as horas de trabalho (LIMA JÚNIOR et al., 2019).

Tecnologias inovadoras no uso de cicatrização de feridas são realizadas em animais de laboratório, mas voltada para a medicina humana, seu avanço proporcionou aplicar não só em pequenos animais, mas também em animais de estimação exóticos. Tais tratamentos são: terapia de pressão negativa de feridas, fotobiomodulação [terapia a laser], terapia de estimulação elétrica [EST], ultrassonografia terapêutica [TU], oxigenoterapia hiperbárica [OHB], expansores de pele, xenoenxertos e pele autóloga por bioengenharia (GONZÁLEZ, MAYER, 2019).

O xenoenxerto que é a retirada da pele de uma espécie e enxertada em outra. O colágeno da tilápia, chamada de nanofibras, possui um custo menor, tem boa estabilidade térmica e podem ser usadas como curativos, promovendo a proliferação de queranócitos e estimulando a diferenciação epidérmica. Nos ratos eles melhoram e aceleram a regeneração da pele, promovendo a adesão e diferenciação celular, já em feridas profundas em coelhos a pele da Tilápia se mostrou um antibacteriano excelente. $\mathrm{O}$ tratamento com a pele da Tilápia foi relatado em literatura não cientifica em um leão e dois ursos. 
Mostrando que o tratamento de curativo biológico oclusivo em feridas usando a pele da Tilápia é um produto inovador, de qualidade e de baixo custo, vindo a servir tanto a espécie humana, quanto para os animais, sendo de pequeno ou grande porte (MIRANDA, BRANDT, 2019).

A pele da Tilápia do Nilo é eficiente

\section{CONCLUSÃO}

O presente estudo identificou, através da revisão integrativa da literatura científica, quão é importante para o sistema de saúde esse inovador curativo biológico oclusivo no tratamento de lesões e queimaduras, até o presente momento o padrão de qualidade da pele da Tilápia do Nilo e a sua aplicação no tratamento de queimaduras e lesões é eficaz, uma vez que a morfologia das peles se assemelha. Este tratamento revolucionário, diminui o sofrimento do paciente e a dor, já que não necessita de trocas de curativos, uma vez que ela se adere ao leito da lesão, ocluindo

\section{REFERÊNCIAS}

ABDEL-SAYED, P. et al. Evolution of biological bandages as first cover for burn patients,

Advances in Wound Care, v. 8, n. 11, p. 555-564, jul. 2019.

ALVES, A. et al. "Study of tensiometric properties, microbiological and collagen content in nile tilapia skin submitted to different sterilization methods", Cell and Tissue Banking, v. 19, p. 373-382, dec. em lesões da pele, principalmente em pacientes queimados, cujo precisam de mais proteção, sendo assim um ótimo curativo biológico oclusivo de baixo custo, boa aderência ao leito da lesão, sem trocas de curativos e com bastante diminuição do nível da dor.

suas terminações nervosas, promovendo uma melhora instantânea da dor, auxiliando na recuperação por não haver tanta manipulação dessa área lesionada, reduzindo assim o tempo de cicatrização da ferida, por possuir propriedades que aumentam a regeneração celular e impede a contaminação externa por bactérias e microorganismos, diminui a perda hídrica, e, portanto, ajuda a minimizar os custos do tratamento dos pacientes no sistema de saúde, sendo um dos melhores tratamentos já encontrados na atualidade, por possuir um baixo custo já que um dos maiores produtores de Tilápia é o Brasil.

2018

ALVES, A. et al. Avaliação microscópica, estudo histoquímico e análise de propriedades tensiométricas da pele de tilápia do Nilo, Revista Brasileira de Queimaduras, v. 14, n. 3, p. 203-210, dec. 2015.

GERENCIAR CITAÇÕES E REFERÊNCIAS. Disponível em: https://www.mendeley.com/downloaddesktop/. Acesso em: 12 set. 2020. GIMENEZ, C. et al. A pele da Tilápia no 
tratamento de queimaduras de segundo e terceiro graus, além de mais eficiente, é de baixíssimo custo, Revista Enfermagem Atual In Derme, v. 87, p. 1-2, apr. 2019. GONZÁLEZ, M. S., MAYER, J. Technological advances in wound treatment of exotic pets, Veterinary Clinics of North America: Exotic Animal Practice, v. 22, n. 3, p. 451-470, sep. 2019.

LEONTSINIS, C. et al. Elaboração de um protocolo para implementação e funcionamento do primeiro banco de pele animal do Brasil: Relato de experiência, Revista Brasileira de Queimaduras, v. 17, n. 1, p. 66-71, mar. 2018.

LIMA JÚNIOR, E. M. et al. Pediatric burn treatment using Tilapia skin as a xenograft for superficial- partial thickness wounds: a pilot study, Journal of Burn Care \& Research, v. 41, n. 2, p. 241-247, aug. 2019.

LIMA JÚNIOR, E. M. et al. Elaboration, development, and installation of the first animal skin bank in Brazil for the treatment of burns and wounds, Revista Brasileira de Cirurgia Plástica, v. 34, n. 3, p. 349-354, jun. 2019.

LIMA JÚNIOR, E. M. et al. Uso da pele de tilápia (Oreochromis niloticus), como curativo biológico oclusivo, no tratamento de queimaduras, Revista Brasileira de Queimaduras, v. 16, n. 1, p. 10-17, jun. 2017.

LIMA-JÚNIOR, E. M. et al. Characterization of the microbiota of the skin and oral cavity of Oreochromis niloticus, Journal of Health and Biological Science, v. 4, n. 3, p. 193-197, sep. 2016.

MEI, F. et al. Collagen peptides isolated from Salmo salar and Tilapia nilotica skin accelerate wound healing by altering cutaneous microbiome colonization via upregulated NOD2 and BD14, Journal of Agricultural and Food Chemistry, v. 68, n. 6, p. 1621-1633, jan. 2020.

MIRANDA, M. J. B. Viabilidade da pele de Tilápia do Nilo (Oreochromis niloticus) como curativo biológico no tratamento de queimaduras: revisão da literatura, Anais da Faculdade de Medicina de Olinda, v. 1, n. 1, p. 49-52, apr. 2018.

MIRANDA, M. J. B., BRANDT, C. T. Xenoenxerto (pele da Tilápia-do-Nilo) e hidrofibra com prata no tratamento das queimaduras de II grau em adultos, Revista Brasileira de Cirurgia Plástica, v. 34, n. 1, p. 79-85, nov. 2018.

NASCIMENTO, A. B. et al. O uso da pele de Tilápia no tratamento de queimaduras,

Temas em Saúde - Edição Especial, v. 1, n. 1, p. 128-143, 2020.

NUNES, R.S., LOPES, K. M. Curativos em queimaduras de terceiro grau, Revista Eletrônica da Faculdade de Ceres, v. 7, n. 1, p. 56-68, nov. 2018.

OBTENÇÃO DE FREQUÊNCIA DE PALAVRAS. Disponível em: https://wordart.com/. Acesso em: 5 ago. 2020.

OUYANG, Q. et al. Chitosan hydrogel in combination with marine peptides from tilapia for burns healing, International Journal of Biological Macromolecules, $v$. 112, p. 1191-1198, jan. 2018.

SILVA, S. et al. Using tilapia skin (Oreochromis niloticus) as an occlusive biological curative in equine wounds: short communication, São Paulo - SP, Brazil, Brazilian Journal of Veterinary Research and Animal Science, v. 56, n. 4, p. e154079, 2019. Disponível em: http://www.periodicos.usp.br/bjvras/article /view/154079. Acesso em: 30 Mar. 2020.

TORRISI, A. et al. Pele da tilápia do Nilo (Oreochromis niloticus) como curativo biológico no tratamento de queimadura: relato de caso, Anais da Faculdade de Medicina de Olinda, v. 2, n. 2, p. 65-68, 2018.

TRADUÇÃO DE IDIOMAS. Disponível em: $\quad$ https://translate.google.com.br/. Acesso em:18 out. 2020.

ZENG, R. et al. Approaches to cutaneous wound healing: basics and future directions, Cell and Tissue Research, v. 374, n. 2, p. 217-232, mar. 2018.

ZHOU, T. et al. Multifunctional and 
biomimetic fish collagen / bioactive glass nanofibers: fabrication, antibacterial activity and inducing skin regeneration in vitro and in vivo, International Journal of Nanomedicine, v. 12, p. 3495-3507, may. 2017. 